\title{
Effect of Coconut Oil, Coconut Water and Palm Kernel Oil on Some Biochemical Parameters in Albino Rats.
}

\author{
Mohammed, $\mathrm{A}^{1}$ and Luka, C.D ${ }^{2}$ \\ ${ }^{I}$ Department of Biochemistry, Faculty of Pure \& Applied sciences, Federal University Wukari, Taraba State, \\ Nigeria. \\ ${ }^{2}$ Department of Biochemistry, Faculty of Medical Sciences, University of Jos, Plateau State, Nigeria.
}

\begin{abstract}
The coconut oil, coconut water and palm kernel oil was administered orally at a dose of $400 \mathrm{mg} / \mathrm{kg}$ body weight to white albino rats to check for some effect on biochemical parameters. Twenty (20) rats divided into four (4) groups of five (5) rats each. One group was treated with distilled water and feed only serving as control, second group was treated with coconut water only while the third group was treated with coconut oil only and the fourth group was treated with palm kernel oil only. The treatment lasted for 7 days. Effect of the coconut oil, coconut water and palm kernel oil on lipid profile, glucose and protein were analysed, also toxic effect was determined using biochemical enzyme markers. Treatment showed significant $(p<0.05)$ decrease in glucose and protein levels. Treatment with coconut oil, coconut water showed significant $(p<0.05)$ decrease in Triglyceride, Total cholesterol, $L D L$ while it shows significant $(p<0.05)$ increase when treated with palm kernel oil. Also, treatment with coconut oil, coconut water showed significant $(p<0.05)$ increase in $H D L$ while treatment with palm kernel oil showed significant $(P<0.05)$ decrease.Treatment with coconut oil, coconut water and palm kernel oil showed a significant $(p<0.05)$ decrease in enzyme activities except for ALP when treated with palm kernel oil, ALT when treated with coconut oil. Treatment with coconut oil, coconut water and palm kernel oil showed hypoglycaemic properties and also shows no toxic effect on the liver at the concentration employed.
\end{abstract}

Keywords: Coconut, palm kernel, lipid profile, enzymes, haematology.

\section{Introduction}

Coconut oil and palm kernel oil are reportedly the only two oils in creation that are made up predominantly Medium Chain Triglycerides (MLT). The medium chain fatty acids (MCFA) are six to twelve carbon chains and are saturated (6:0, 8:0, 10:0, and 12:0) they made up about two thirds of coconut oil fatty acids. Medium chain triglycerides are reportedly absorbed in the intestines, even without pancreatic lipase, they are carried by portal vein to the liver where they are rapidly oxidised to produce energy [1]. Medium chain triglycerides (MCT) unlike low chain triglycerides (LCT) do not enter the cholesterol cycle, are not deposited in fat depots hence do not cause obesity [1]. As the coconut matures the pulp becomes firmer with less water and its nutrients are more of carbohydrate (6.23\%), protein (3.33\%) and mineral salt particularly magnesium, calcium and phosphorus [2]. Palm kernel oil is edible plant oil derived from the kernel of the oil palm ELAEIS GUINEESIS [3]. Like all vegetable oils these three palms derived oils namely palm kernel oil, coconut oil and palm oil do not contains cholesterol (found in unrefined animal fats) [4]. Although saturated fats intake increases both low density lipoprotein (LDL) and high density lipoprotein (HDL) [5]. Palm kernel oil is common cooling ingredient with lack cholesterol and trans-fatty acids both viewed as being heart healthy attributes.

The coconut is an important member of the family Arecaceae (palm family). It is the only accepted species in the genus cocos [6], and is a large palm growing up to $30 \mathrm{~m}$ tall, with pinnate leaves $4-6 \mathrm{~m}$ long and pinnae $60-90 \mathrm{~cm}$ long, old leaves break away clearly leaving the truck smooth. Coconut forma part of daily diet, the oil is used for cooking; coir is used for furnishing and decorating. The coconut water belongs to the family of the palmate the tridecocoideae and to the genus cocosnucifera. The water of a tender coconut technically the liquid endosperm contain sugar, mineral, protein, free amino acids and growth promoting factors [7]. It has numerous medicinal properties which according to include; good drink for cholera patients because of its saline and albumin content, checking urinary infections and diarrhoea, effective in the treatment of kidney and urethral stones, aiding in quick absorption of drugs and makes their peak concentration in the blood easier by its electrolytes effects and eliminates poisons in case of mineral poisoning [8]. Coconut has been implicated in the treatment and management of prostate pathologies [2]. 
Collection of plants materials

\section{Materials and Methods}

The fresh Coconut and Palm Kernel were bought at Bukuru market in Jos South LGA of Plateau State and were authenticated at the Botany Department of University of Jos.

\section{Collection of Experimental Animals}

Sixteen matured male Wister strain albino rats weighing between $115-250 \mathrm{~kg}$ were obtained from the Animal House Unit of University of Jos.

\section{Extraction of coconut oil and palm kernel oil}

Coconut oil was prepared by shelling the nut and the meat using a dull knife, the brown skill was removed from the coconut meat with razor blade, the meat was thoroughly washed and later grated. The grated meat was put in a bowl and a little warm water was added and left for a few minutes to extract the oil. The extract was laterallowed to settle and oil rise up and was sieved out of the extract.Palm kernel oil prepared by shelling the nut from the kernel and separated from the shell using hammer. The kernel was thoroughly washed, pounded and was put in a bowl and little warm water was added and left for a few minutes to extract the oil. The extract was later allowed to settle and the oil rise up and the oil was sieved out of the extract. Coconut water was obtained from tender coconut technically the liquid endosperm.

\section{Administration of the oil}

The coconut water, coconut oil and palm kernel oil was given orally at a dose of $1 \mathrm{ml} / \mathrm{kg}$ body weight daily. This was carried out for 7 consecutive days.

\section{Experimental grouping}

The rats were divided into four groups of four rats each and were allowed to acclimatize for three days before the commencement of the experiment.

The grouping and administration of the extracts is as follows:

\begin{tabular}{|c|c|c|c|}
\hline GROUP & Title & No of rats & Treatment \\
\hline A & Control & 4 & Distilled water + feed \\
\hline B & Coconut oil & 4 & Coconut oil \\
\hline C & Coconut water & 4 & Coconut water \\
\hline D & Palm kernel oil & 4 & Palm kernel oil \\
\hline
\end{tabular}

\section{Determination of Serum Glucose Levels}

Glucose was determined after an enzymatic oxidation in the presence of glucose oxidase using kit product of Randox UK. [9]

\section{Determination of Serum TotalProtein Levels}

The total protein was determined using biuret method.

\section{Determination of Serum Triglyceride Levels}

Triglyceride was determined after hydrolysis by lipase to yield glycerol and free fatty acid using glycerol phosphate oxidase method. [10]

\section{Determination of Enzymatic Activities}

The determination of serum alanine aminotransferase, aspartate aminotransferase and alkaline phosphatase activities were done using kit product of Randox UK [9].

\section{Statistical analysis}

All data are express as Mean (x) \pm Standard Deviation (SD). The result were analysed by one-way Anova and were applicable least significant differences (LSD) was used to determine significant result. Differences between groups were considered significant at $\mathrm{P}<0.05$. 


\section{Results}

TABLE I: Effect of Coconut Oil, Coconut Water and Palm Kernel Oil on Serum Glucose and Serum Total Protein.

\begin{tabular}{|l|l|l|}
\hline TREATMENT & GLUCOSE $($ Mmol/L) & PROTEIN $(g / \mathbf{l})$ \\
\hline Coconut oil & $4.2 \pm 0.26^{\mathrm{a}}$ & $2.0 \pm 0.2^{\mathrm{a}}$ \\
\hline Coconut water & $3.4 \pm 026^{\mathrm{a}}$ & $4.5 \pm 0.2^{\mathrm{a}}$ \\
\hline Palm kernel oil & $4.0 \pm 0.26^{\mathrm{a}}$ & $4.3 \pm 0.2^{\mathrm{a}}$ \\
\hline Control & $4.5 \pm 0.2$ & $4.9 \pm 0.1$ \\
\hline
\end{tabular}

Values are presented as mean \pm SD for 4 determinations, $n=4$

$\mathrm{a}=$ statistically significant decrease when compared with control $(\mathrm{P}<0.05)$

$\mathrm{b}=$ statistically not significant when compared with control $(\mathrm{p}>0.05)$

$c=$ statistically not significant when compared with control $(p>0.05)$

TABLE II: Effect of Coconut oil, Coconut Water and Palm Kernel oil on Serum Lipid Profile Levels.

\begin{tabular}{|l|l|l|l|l|}
\hline Treatment & T.G(Mmol/L) & T.C(Mmol/L) & LDL(Mmol/L) & HDL(Mmol/L) \\
\hline Coconut oil & $1.28 \pm 0.56^{\mathrm{d}}$ & $2.59 \pm 0.01^{\mathrm{b}}$ & $1.14 \pm 0.01^{\mathrm{c}}$ & $3.36 \pm 0.01^{\mathrm{c}}$ \\
\hline Coconut water & $1.20 \pm 0.59^{\mathrm{d}}$ & $2.59 \pm 0.01^{\mathrm{b}}$ & $1.06 \pm 0.01^{\mathrm{c}}$ & $2.96 \pm 0.01^{\mathrm{c}}$ \\
\hline Palm kernel oil & $2.16 \pm 0.01^{\mathrm{c}}$ & $2.83 \pm 0.01^{\mathrm{c}}$ & $1.66 \pm 0.01^{\mathrm{c}}$ & $2.36 \pm 0.01^{\mathrm{c}}$ \\
\hline Control & $1.61 \pm 0.01$ & $2.59 \pm 0.01$ & $1.31 \pm 0.01$ & $2.85 \pm 0.01$ \\
\hline
\end{tabular}

Values are presented as mean \pm SD for four determinations, $n=3$

$\mathrm{b}=$ not statistically significant when compared with control $(\mathrm{P}>0.05)$

$\mathrm{c}=$ statistically significant when compared with control $(\mathrm{P}<0.05)$

$\mathrm{d}=$ statistically significant when compared with control $(\mathrm{P}<0.05)$

TABLE III:Effect Coconut oil, Coconut Water and Palm Kernel oil on Serum Enzyme Levels

\begin{tabular}{|l|l|l|l|}
\hline Treatment & ALP $(\mathrm{U} / \mathrm{L})$ & AST $(\mathrm{U} / \mathrm{L})$ & ALT $(\mathrm{U} / \mathrm{L})$ \\
\hline Coconut oil & $24.0 \pm 5.0^{\mathrm{c}}$ & $52.2 \pm 0.2^{\mathrm{c}}$ & $90.2 \pm 0.2^{\mathrm{c}}$ \\
\hline Coconut water & $17.1 \pm 0.1^{\mathrm{c}}$ & $45.5 \pm 0.2^{\mathrm{c}}$ & $65.5 \pm 0.2^{\mathrm{c}}$ \\
\hline Palm kernel oil & $68.6 \pm 0.1^{\mathrm{c}}$ & $59.5 \pm 0.2^{\mathrm{c}}$ & $11.7 \pm 1.5^{\mathrm{c}}$ \\
\hline Control & $34.3 \pm 0.2$ & $63.0 \pm 2.5$ & $69.7 \pm 0.1$ \\
\hline
\end{tabular}

Values are presented as $\pm \mathrm{SD} ; \mathrm{n}=3$

$\mathrm{C}=$ statistically significant when compared with control $(\mathrm{P}<0.05)$

\section{Discussion}

The Wister rats used were strictly males because it was reported that female sex hormones (17ßestradiol) has a lowering effect on the plasma cholesterol concentration [11]. Thus, using female rats may interfere with the accuracy of the serum cholesterol level, since it was one of the parameters analysed.Glucose is important in the body because it is stored in mainly the liver and muscles as glycogen; it is distributed and utilized in tissues as free glycogen. Protein is also important in the function of growth and cell maintenance; proteins are responsible for muscle contraction. Scientists can speculate on the reasons why glucose and not another monosaccharide such as fructose, is so widely used in organisms. One reason might be that glucose has a lower tendency, relative to other hexose sugar to react non-specifically with the amino groups of protein. The reaction (glycation) reduces or destroys the function of many enzymes. The low rate of glycation is due to glucose preferences for the less reactive cyclic isomer [12]. Nevertheless, many of the long term complications of diabetes e.g. blindness, renal failure and peripheral neuropathy are probably due to the glycation of the proteins or lipids. However, enzyme regulates addition of glucose to protein by glycosylation which is often essential to their function [14]. Treatment with coconut oil, coconut water and palm kernel oil shows significant $(\mathrm{P}>0.05)$ decrease in both glucose and protein levels.

Lipids profile also known as coronary (heart attack) risk panel, or lipid panel the collective term to the estimation of typically total cholesterol, high density lipoprotein and triglycerides are used to assess risk of coronary heart disease [13]. Lipid profiles have been shown to be the important predictors for the metabolic disturbances including dyslipidemia, hypertension, diabetes, cardiovascular disease, hyperinsulinemia etc. [5]. Treatment with coconut oil, coconut water shows significant $(\mathrm{P}<0.05)$ decrease in total cholesterol, triglyceride, LDL level but shows significant $(\mathrm{P}<0.05)$ Increase in HDL when treated with palm kernel oil. Treatment with coconut oil, coconut water shows significant $(\mathrm{P}<0.05)$ increase in $\mathrm{HDL}$ while it shows significant $(\mathrm{P}<0.05)$ decrease in HDL when treated with palm kernel oil. 
Changes in serum enzymes levels are often early determinant of tissue damage either by toxicant or in disease conditions. Serum alkaline phosphate, alanine aminotransferase and aspartate aminotransferase are liver biochemical markers. Therefore, increases in ALT activity are always due to hepatocellular damage and it is usually accompanied by AST activity [14]. However, the difference observed in the activities of these enzymes at the dose employed $(400 \mathrm{mg} / \mathrm{kg}$ body weight) showed statistically significant $(\mathrm{P}>0.05)$ decrease in enzymes activities except for ALP and ALT when treated with palm kernel oil and coconut oil respectively which showed slight increase. This implies that coconut oil, coconut water and palm kernel oil at that concentration employed has no toxic effect on the liver of the rats.

\section{Conclusion}

Treatment with coconut oil, coconut water and palm kernel oil decreased the concentration of glucose and protein in the experimental rats. Therefore, the plants have hypoglycaemic effects. The study also showed that coconut oil, coconut water and palm kernel oil may not have toxic effect on the liver at the employed dosage since it produced no significant effects on the enzymes activities as biochemical enzymes makers of liver damage.

\section{References}

[1] Dayrit, C.S. Coconut oil: Atherogenic or not? (What therefore causes atherosclerosis?). Philippine journal of cardiology, 31(3) 2003, 397-104.

[2] Pamplona-Roger. Coconut has been implicated in the treatment and management of prostate pathogens. 2005, $187-217$.

[3] Poku, Kwasi.“Origin of oil palm”.Small palm oil processing in Africa.Agricultural services.Food and agricultural organization (FAO).2002, 277-312.

[4] US federal food, drugs and cosmetic act, 21 CFR 101.25 as amended in federal register 1990, 55, 139, 29472.

[5] Mensink, R.P., Katan, M.B. Effect of dietary fatty acid on serum lipids and lipoproteins. 1992

[6] William, J.H. Arecanae: "The palms, tolweb.org.version. 1997, 217-332.

[7] Muanya, C. Researchers validate coconut water as nature's energy drink. 2009.

[8] Cocoinfo international. 2004, 2, 1: ISBN 0854-5006

[9] Barham, D and Trinder, P. An improved colour reagent for the determination of blood glucose by oxidase systems.1972, 97, 142.

[10] Trinder, P. Ann. Clinical biochemistry. 1969, 6, 24

[11] Adoga, G.I and Glew, R.H. Effect of garlic oil on some Biochemical Parameters in streptozotocin induced diabetic rats. 1995, 18, $859-860$

[12] Vasudevam, D.M andSreekumari S. Textbook of Biochemistry for Medical Students. 2005, 4.

[13] Effiong, G.S. Department of Clinical Pharmacy and Biopharmacy, Faculty of Pharmacy, University of Uyo. Akwa-Ibom. 2007.

[14] Sekar, N, William, S, Balasubramanniyam, N and Kamarajan, P. Optimization of sodium orthoranadate to treat streptozotocin induced diabetic rats. J. Biosci.1990, 15, 67-75. 